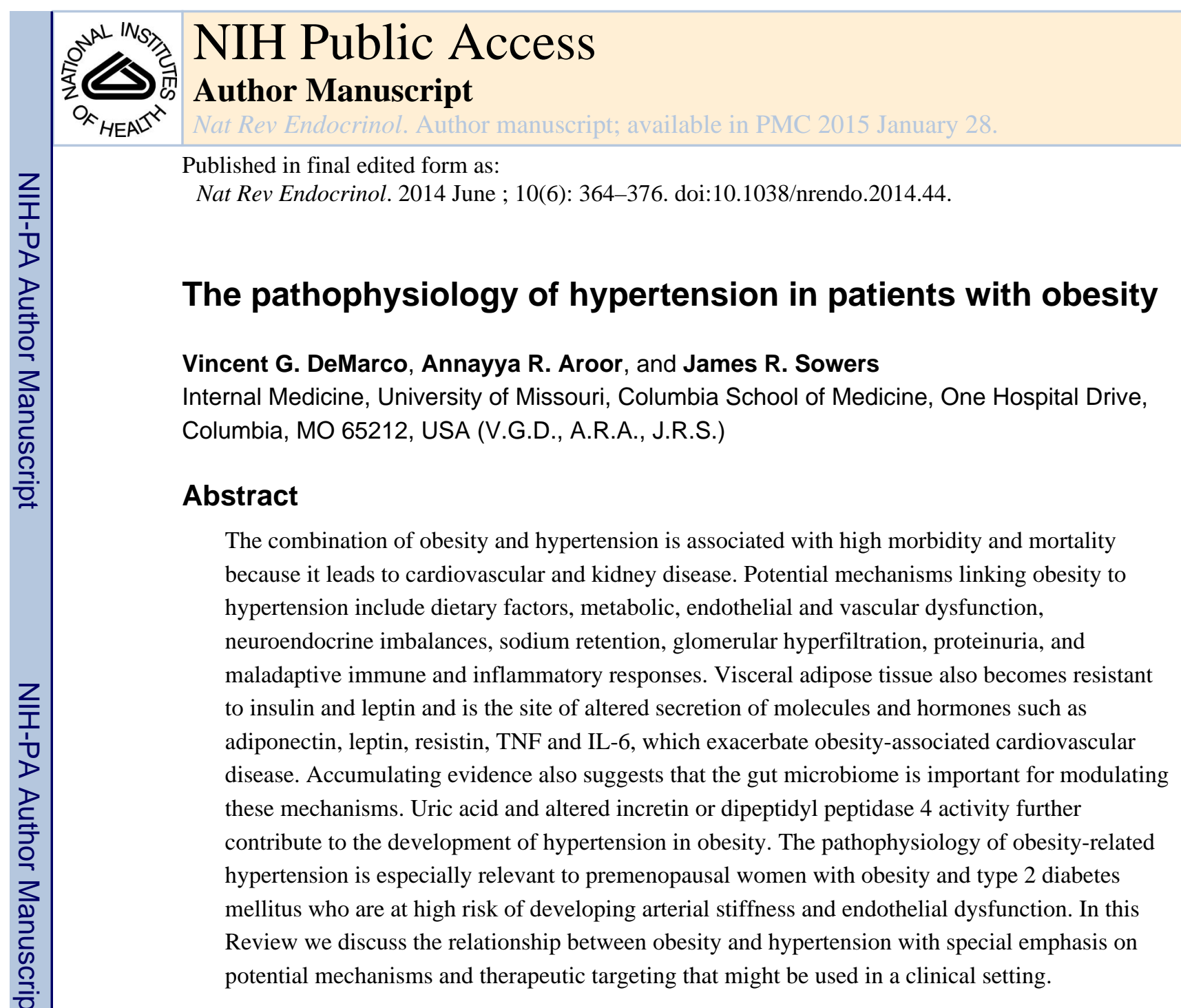

\title{
Introduction
}

Epidemiological data indicate that the current global obesity epidemic began approximately 40 years ago, ${ }^{1}$ however, some studies suggest that the rise in obesity rates started earlier, and that the progression of the epidemic has been somewhat irregular. ${ }^{2-4}$ The causes of the obesity epidemic are most frequently ascribed to two factors: the combination of institutionally driven decreases in physical activity (for example, reductions in school physical education classes and the sedentary nature of most modern vocations); and overnutrition resulting from modern food marketing practices and technology (such as inappropriately large portion sizes in restaurants and processed foods and the ready availability of inexpensive high-calorie fast food). ${ }^{4,5}$ However, evidence also suggests that additional factors might contribute to the obesity epidemic, including sleep debt, endocrine

(C) 2014 Macmillan Publishers Limited. All rights reserved

Correspondence to: J.R.S. sowersj@ health.missouri.edu.

Competing interests

The authors declare no competing interests.

Author contributions

V.G.D. and A.R.A. contributed equally in preparing all aspects of the manuscript. J.R.S. made substantial contributions to discussion of the content, and read and edited the manuscript before submission. 
disruptors and intrauterine and inter-generational effects, and these have been extensively reviewed elsewhere. ${ }^{4,6}$ Obesity is a major public health burden in the USA and $>300,000$ deaths each year are attributable to obesity or being overweight. ${ }^{7,8}$ In the USA, among the adult population of $\sim 240$ million individuals, $>65 \%$ are overweight and, of these, half have obesity; ${ }^{9}$ moreover, approximately 13 million US children are also estimated to have obesity. ${ }^{10}$ Worldwide, in both developed and developing nations, one billion people are either overweight or have obesity, making this disorder a global epidemic. ${ }^{11}$

In 1967, a prospective analysis of data from the Framingham Heart Study highlighted the relationship between obesity and hypertension. ${ }^{12}$ Indeed, the high prevalence of hypertension among patients with obesity ( $>60 \%)$ accounts for $78 \%$ of incident hypertension in men and $64 \%$ of incident hypertension in women. ${ }^{13-15}$ The prevalence of hypertension increases in relation to BMI in both men and women after adjusting for age. ${ }^{16,17}$ Estimates indicate that the increased risk of developing hypertension is $20-30 \%$ for every $5 \%$ increment in weight gain. ${ }^{18}$ Even before the Framingham Heart Study data, researchers reported on the potential mechanisms of hypertension in patients with obesity by linking the cardiovascular and metabolic complications of obesity to adipose tissue that is distributed primarily at and above the waistline (that is, upper-body obesity). ${ }^{19}$ Contemporaneous studies reported metabolic abnormalities associated with upper-body obesity, including insulin resistance and hypertriglyceridaemia. ${ }^{20,21}$ This concept was further refined in the 1980s when researchers demonstrated that an increase in the waist-to-hip ratio was associated with increased risk of hypertension. ${ }^{22-24}$ The clustering of abdominal obesity, hypertension, insulin resistance and hypertriglyceridaemia was, therefore, the key to later development of the concepts of the metabolic syndrome and cardiorenal syndrome (CRS) ${ }^{25,26}$ Clinical trials have, for the most part, demonstrated that weight loss of $\sim 10 \%$ of original body weight by calorie restriction and/or increased activity is an effective means to achieve clinically meaningful reductions in blood pressure and mortality from cardiovascular disease (CVD). ${ }^{27,28}$

Several other reviews have focused on specific factors contributing to obesity-associated hypertension. ${ }^{29-37}$ In this Review, we present an integrated view of the pathophysiology of obesity-associated hypertension and discuss the relationships between the multiple factors contributing to this condition. We also discuss factors that contribute to obesity-associated hypertension, including incretin signalling, dysfunctional immunity and the gut microbiome, as well as specific antihypertensive therapies especially relevant to patients with obesity.

\section{Obesity and hypertension}

Progression from a normotensive to hypertensive phenotype results from a combination of genetic, environmental, behavioural and dietary factors (Figure 1). The combination of obesity and hypertension has two important consequences. Firstly, this combination is particularly insidious in that the population with obesity and hypertension have high morbidity and mortality from CVD, including coronary heart disease, congestive heart failure, sudden cardiac death, chronic kidney disease (CKD), end-stage renal disease and stroke. ${ }^{29}$ Secondly, obesity increases the risk of treatment-resistant arterial hypertension, which therefore requires multiple medications and device therapy, such as renal sympathetic 
denervation. ${ }^{7,38}$ Conversely, in population studies, future weight gain is significantly higher in patients with hypertension than in normotensive individuals, indicating that hypertension per se contributes to the increased risk of obesity ${ }^{12}$ and implying a further link between obesity and hypertension.

Before menopause women are protected against CVD, including hypertension, compared with age-matched men owing to the cardioprotective effect of estrogen; ${ }^{39}$ however, in the setting of obesity or type 2 diabetes mellitus (T2DM) this protection is lost. ${ }^{40-43}$ Population studies indicate that women who are premenopausal but obese have a substantially higher risk of developing hypertension (43-56\%) than age-matched men with obesity (20-27\%). ${ }^{44}$ Weight loss of 5-10 kg in women with obesity substantially lowers the risk of developing hypertension by up to $25 \% .{ }^{45,46}$ Moreover, maternal and paternal obesity also seem to increase the risk of offspring to develop obesity and hypertension in early adult life. ${ }^{32,47,48}$ Given the differences in cardiovascular physiology between sexes, women might require female-specific and more aggressive therapeutic and lifestyle management for obesity and its cardiovascular complications than men. ${ }^{41}$

\section{Dietary factors}

\section{Fructose, fat and sodium}

The current global obesity epidemic has primarily been ascribed to excess consumption of energy-dense foods, which are high in sugar, fat and sodium, in combination with an increasingly sedentary lifestyle. ${ }^{1}$ The introduction of high-fructose corn syrup (HFCS) in 1967 in the USA, and its dramatic increase in consumption compared with other carbohydrates between 1970 and 1990, has been related to obesity, CRS and diabetes mellitus. ${ }^{37,49,50}$ HFCS is more lipogenic than other sugars and increases the circulating levels of triglycerides, insulin, glucose and LDL cholesterol, ${ }^{51}$ factors that increase the risk of progression to the metabolic syndrome and CVD. Increased HFCS consumption is also associated with elevated uric acid synthesis (a property that is unique among sugars ${ }^{51}$ ) and emerging evidence supports a role for uric acid in the development of hypertension and CVD. ${ }^{37,52}$ However, the hypothesis that fructose and uric acid can induce hypertension is controversial. For example, in rodent studies, conflicting reports suggest that fructose consumption can lead to either no change $\mathrm{e}^{53}$ or an increase ${ }^{54,55}$ in blood pressure. These differences might be attributable to the methodology used to measure blood pressure, ${ }^{53,56}$ if fructose is dissolved in water (like in a sweetened beverage) or consumed in addition to high-fat or high-salt diets. ${ }^{53,56,57}$ Results reported in clinical studies are equally controversial owing to differences between study design, treatment duration, variability of nutrient composition or form of fructose added to the diet (for example, fructose, HFCS, sucrose, or natural fruits). ${ }^{57}$ Investigators have presented consistent evidence supporting the observation that reducing sodium intake can lead to reductions in blood pressure. ${ }^{58,59}$ However, administering fructose with a high-salt diet leads to hypertension that persists even after removal of fructose from the diet. ${ }^{54}$ Similarly, mice fed with a combination of high-fructose and high-fat diet for 6 months also develop hypertension. ${ }^{56}$ These results suggest a synergistic deleterious effect owing to the interaction of fructose with either salt or 
high fat content. Additional well designed prospective studies are, therefore, needed to determine the effect of HFCS in the development of obesity-associated hypertension. ${ }^{50}$

\section{Cardioprotective nutrients}

The undesirable dietary changes in the USA during the past 50 years might be further exacerbated by the imbalance in consumption of omega- 6 and omega- 3 fatty acids. Omega- 3 fatty acids must be obtained from an individual's diet. Humans evolved on diets that contained fairly equal amounts of omega- 6 and omega- 3 fatty acids. However, in the past 50 years the US diet has become deficient in omega-3 fatty acid (ratio of omega- 6 to omega-3 $\sim 15: 1$ ) owing to increased consumption of plant-derived oils (soybean and corn oils) and red meat from grain-fed animals, which are rich in omega- 6 but not omega- 3 fatty acids. ${ }^{60}$ Consequently, cold water marine fish have received much attention by dieticians due to their high content of omega- 3 and more balanced ratio of omega- 6 to omega- 3 fatty acids. In meta- analyses, fish oil supplements lower blood pressure in patients with hypertension. ${ }^{61,62}$ However, the reports that fish oils can prevent CVD in general are inconclusive. ${ }^{63}$

Combination diets, notably the Dietary Approaches to Stop Hypertension (DASH) diet, ${ }^{64}$ which is rich in nutrients from fruits, vegetables and has modest levels of sodium, omega-3 and omega- 6 fatty acids, have emerged as part of a balanced strategy for the management of hypertension. Approaches such as the DASH diet include green leafy (for example, cabbages, spinach and lettuces) and root (carrots and beets) vegetables that are rich in inorganic nitrate. ${ }^{65}$ Beetroot juice, which also contains high levels of inorganic nitrate, can also lower blood pressure. ${ }^{66,67}$ The nitrate content of these foods is likely to contribute to increased nitric oxide (NO) bio-availability, which has multiple beneficial pleiotropic effects in the vasculature such as vasodilation. ${ }^{68}$

\section{Gut microbiota, obesity and hypertension}

Emerging evidence suggests that changes in the gut bacterial microbiome, associated with genetic and dietary factors, can lead to metabolic disorders that result in obesity, insulin resistance, T2DM and hypertension. ${ }^{69,70}$ In $o b / o b^{71,72}$ and $d b / d b^{73}$ mice, the number of caecal bacteria from the phylum Bacteroidetes (so called 'good bacteria') is reduced, which is accompanied by a proportional increase in the number of bacteria from the phylum Firmicutes (so called 'bad bacteria'). Bacterial-derived lipopolysaccharides are thought to regulate hormones such as apelin in adipose tissue that alter glucose homeostasis and inflammation. ${ }^{73}$ Mice fed a high-fat diet have progressive increases in the number of Firmicutes suggesting that the quality of the diet can modulate the gut microbiome. ${ }^{74}$ Changes in the gut microbiome lead to abnormalities in pattern recognition receptor function, immune and inflammatory responses, and insulin sensitivity. ${ }^{75}$ These studies suggest that therapeutic manipulation of the gut microbiome (for example, by faecal transplantation or oral prebiotic or probiotic preparations) might potentially suppress immune and inflammatory responses and improve insulin sensitivity — a novel approach that might be used to manage obesity and hypertension in humans. ${ }^{76,77}$ 


\section{Mechanisms of hypertension in obesity}

The development of hypertension in patients with obesity is dependent on the interactions between dietary, genetic, epigenetic, and environmental factors (Figure 1). ${ }^{78,79}$ Adipocyte dysfunction in patients with obesity contributes to vascular and systemic insulin resistance and the dysfunction of the sympathetic nervous system (SNS) and the renin-angiotensinaldosterone system (RAAS). ${ }^{7,78}$ Structural and functional changes in the kidney, including activation of intrarenal angiotensin II (Ang II), are also important in the development of obesity-associated hypertension. ${ }^{80}$ For example, some investigators have suggested that arterial hypertension in lean patients is mediated by an increase in peripheral vascular resistance, whereas hypertension in individuals with obesity is mediated, in part, by increased intravascular volume, cardiac output, ${ }^{81}$ and proximal tubule sodium absorption in the kidney. ${ }^{82}$ However, crosstalk between components of the intravascular RAAS, specifically Ang II and aldosterone, can also regulate vasoconstriction independently of renal control. ${ }^{83,84}$ Accumulating evidence also suggests that uric acid might affect adipocyte function, and lead to vascular and renal injury. ${ }^{37,85}$ Moreover, incretin signalling is also an important modulator of insulin resistance and immune function. ${ }^{86}$

The interplay between genetic and environmental factors (that is, epigenetic mechanisms) might also contribute the pathophysiology of obesity-associated hypertension. ${ }^{79,87}$ Epigenetic mechanisms include changes in DNA methylation, histone modifications and microRNA (miRNA) regulation. ${ }^{88}$ For example, the miRNAs miR- 142-3p and miR-140-5p are increased in patients with morbid obesity, and are biomarkers of the disease. ${ }^{89,90}$ Epigenetic factors are also relevant to the development of obesity-related hypertension, ${ }^{91,92}$ and might contribute to in utero epigenetic programming, which has been used to explain the origins of fetal and infant diseases. ${ }^{93,94}$ Accumulating evidence suggests that environmental factors during early life might also program the development of obesity and hypertension, but these aspects are beyond the scope of this Review. ${ }^{29,32}$

\section{Vascular injury}

Endothelial dysfunction and arterial stiffness are thought to be the earliest manifestations of vascular dysfunction in obesity and precede the development of prehypertension and hypertension (Figure 1). ${ }^{95-98}$ Increased arterial stiffness is seen in patients who are normotensive but have obesity and who are predisposed to develop hypertension; moreover, incident hypertension is more robustly predicted in patients who are in the highest quartile of arterial stiffness. ${ }^{95-98}$ Changes in the extracellular matrix ${ }^{99}$ and vascular smooth muscle dysfunction ${ }^{100}$ contribute to arterial stiffness; however, accumulating evidence suggests that endothelial dysfunction also contributes to vascular stiffness, which is in turn strongly associated with insulin resistance. ${ }^{98,101}$ Impaired vascular reactivity to insulin before the onset of hypertension is seen in spontaneously hypertensive rats, ${ }^{102}$ suggesting that insulin resistance is an early event in hypertension development. In the vasculature two components of insulin signalling exist: metabolic and growth factor signalling. Metabolic signalling involves insulin receptor substrate-1 (IRS-1), phosphoinositide 3-kinase, protein kinase B (AKT), and endothelial nitric oxide synthase (NOS); growth factor signalling functions via the extracellular signal regulated kinases (ERK)1/2 and endothelin-1 (ET-1) 
pathways. ${ }^{84,103-105}$ In insulin resistant states, metabolism is impaired owing to serine phosphorylation of IRS-1, which leads to reduced NO bioavailability and impaired vascular relaxation. ${ }^{103}$ Conversely, in this state, upregulation of the ET-1 pathway contributes to increased vascular contraction. ${ }^{103}$ The imbalance in pathway-selective insulin signalling in obesity can, therefore, contribute to endothelial dysfunction and arterial stiffness.

In patients with obesity, metabolic changes in adipose tissue lead to altered secretion of bioactive molecules and hormones—collectively referred to as adipokines — such as angiotensinogen, aldosterone stimulating factor, dipeptidyl peptidase 4 (DPP-4), leptin, resistin, TNF and IL-6 (Figure 1). These factors can contribute to obesity-associated insulin resistance and hypertension. ${ }^{106}$ Impaired adiponectin secretion also promotes insulin resistance. ${ }^{78,107,108}$

\section{Renal injury}

Abnormal renal function also leads to hypertension in patients who have obesity, as well as in animal models of obesity (Figure 1). ${ }^{109}$ Obesity increases tubular absorption of sodium and promotes a compensatory shift in the pressure natriuresis curve towards higher blood pressure in response to elevated plasma sodium levels. ${ }^{78,110}$ Moreover, these effects on sodium and pressure natriuresis can be caused by an increase in adipose tissue mass and extracellular matrix accumulation, which compress the renal medulla. Hyperinsulinaemia and inappropriate RAAS and SNS activation also contribute to increased sodium resorption. ${ }^{78}$ Renal vascular remodelling, characterized by inflammation, endothelial dysfunction and vascular smooth muscle proliferation, is seen in humans and animals with hypertension. ${ }^{111}$ Tubulointerstitial inflammation owing to a systemic immune and inflammatory response, elevated uric acid levels, tubulointestinal infiltration of immune cells, circulating proinflammatory immune cells and enhanced inflammation, oxidative stress and fibrosis collectively contribute to renal damage. $37,50,78,112$

The kidney regulates plasma glucose levels by reabsorbing almost all of the glucose filtered by the glomeruli ( 162 g per day). ${ }^{113}$ Glucose reabsorption is primarily localized to the S1 segment of the proximal convoluted tubule and functions via high-capacity, low-affinity sodium-glucose cotransporter-2 (SGLT2). ${ }^{114}$ In humans with diabetes mellitus, ${ }^{115}$ Zucker diabetic fatty rats, ${ }^{116}$ and $d b / d b$ mice ${ }^{117}$ SGLT2 expression is increased in the proximal convoluted tubule, which correlates with glomerular hyperfiltration leading to increased glucose reabsorption. ${ }^{117}$ This increased reabsorption leads to elevated plasma glucose levels and glucose toxicity, and sodium reabsorption, which also contributes to sodium retention. ${ }^{118}$ In hypertensive rats, Ang II regulates the increase in SGLT2 expression via the angiotensin II type 1 receptor $\left(\mathrm{AT}_{1} \mathrm{R}\right)$, supporting a role for SGLT2-mediated sodium reabsorption in the development of hypertension. ${ }^{119,120}$ Moreover, in vivo data suggest that insulin is an agonist for this effect of SGLT2 in humans and is important for postprandial glucose and sodium reabsorption. ${ }^{121}$ Emerging evidence also indicates that inhibition of SGLT2, with molecules such as dapagliflozin, in animal models or humans with T2DM induces a mild osmotic/ natriuretic effect that promotes modest reductions in blood pressure and body weight, which might reduce the risk of a future cardiovascular event. ${ }^{122-124}$ 


\section{SNS overactivation}

Obesity is associated with activation of the SNS in diverse tissues-including the heart, kidneys, and skeletal muscle - and with baroreflex dysfunction, leading to altered blood pressure. ${ }^{33,34,125,126}$ Regardless of blood pressure, individuals who are obese have increased renal SNS activity compared with healthy individuals, indicated by an elevation in renal norepinephrine levels. ${ }^{33}$ Interestingly, individuals who have obesity but are normotensive have suppressed cardiac SNS activity, whereas those who have obesity and hypertension have elevated cardiac SNS activity. ${ }^{33}$ Increases in both renal and cardiac SNS activity might, therefore, be one mechanism that leads to the development of hypertension in obesity. The importance of SNS activation in the kidney to obesity-related hypertension is highlighted by evidence that renal denervation can lower blood pressure and increase sodium excretion in a canine model fed on a high-fat diet. ${ }^{127}$ However, other studies suggest that SNS activation alone might not lead to the development of hypertension. Increased aadrenergic-mediated vascular tone has been reported in overweight men, most of whom had hypertension; ${ }^{128}$ however, hypertension, rather than body weight, might account for the increase in SNS activity reported in this study. In individuals who have obesity but are normotensive the observed increase in sympathetic outflow to the forearm musculature does not lead to an increase in peripheral sympathetic vascular tone. ${ }^{129}$ The authors speculated that a dissociation between SNS activity and peripheral vascular tone can protect a subset of individuals with obesity from developing hypertension, which might explain the small population of individuals with obesity but normal blood pressure. ${ }^{129}$ However, definitive evidence that hypertension in individuals with obesity is either initiated or maintained solely by a neurogenic mechanism has yet to be determined. ${ }^{130}$

Several factors have been suggested to promote obesity-associated hypertension by activating the SNS, including hyperinsulinaemia, hyperleptinaemia, RAAS activation (via Ang II), baroreflex dysfunction and obstructive sleep apnoea (OSA) (Figure 1). ${ }^{131,132}$ However, evidence suggests that hyperinsulinaemia itself does not promote hypertension. ${ }^{133,134}$ Increased leptin secretion from dysfunctional adipose tissue is also an important modulator of SNS activity. ${ }^{131}$ Disruption of signal transducer and activator of transcription 3 (commonly known as STAT3) signalling in the arcuate nucleus leads to resistance to the anorexic effects of leptin and might result in weight gain. ${ }^{135}$ Conversely, preservation of leptin sensitivity in the ventromedial and dorsomedial hypothalamus, involving activation of PI3 kinase and melanocyte stimulating hormone and its receptors, leads to enhanced renal sympathetic outflow. ${ }^{131,132}$ Low adiponectin and increased apelin levels are linked to SNS activation, although their role in SNS regulation is unclear. ${ }^{108,136}$

Progression to a chronic hypertensive state in individuals with obesity might be preceded by a loss of nocturnal blood pressure dipping in the absence of elevated daytime blood pressure. ${ }^{137,138}$ A non-dipping pattern of circadian blood pressure increases the risk of CVD and CKD. ${ }^{137,139}$ The exact mechanisms for this non-dipping pattern of blood pressure are unknown; however, insulin resistance, autonomic nervous system dysfunction, increased SNS activity and increased inflammation can all contribute to the phenomenon. ${ }^{137,140}$

OSA and hypertension are typically associated comorbidities. 50-60\% of individuals with OSA are hypertensive and half of individuals with hypertension have OSA. ${ }^{141}$ Moreover, 
the frequency of the association of these comorbidities is even higher in those with treatment-resistant hypertension. ${ }^{142,143}$ OSA activates the SNS independently of obesityrelated mechanisms ${ }^{144,145}$ and, therefore, might be a major factor that promotes treatmentresistant hypertension in those who have obesity. Renal sympathetic denervation has led to positive improvements in blood pressure, OSA and glycaemic control in patients with obesity and treatment-resistant hypertension. ${ }^{14,38,146}$ OSA is also highly prevalent among individuals with treatment-resistant hypertension and elevated aldosterone levels. ${ }^{146}$ SNS activation and aldosterone production in response to non-classical adrenal stimuli might contribute to the increased aldosterone levels seen in patients with obesity (Figure 2). ${ }^{146,147}$ Aldosterone regulates blood pressure via mineralocorticoid receptors in both the renal and vascular systems. ${ }^{148}$ Treatment with a continuous positive airway pressure assist device and mineralocorticoid receptor inhibitors to limit the deleterious effects of elevated aldosterone levels can reduce the severity of OSA and normalize blood pressure (Figure 2). ${ }^{146}$

\section{RAAS}

In patients with obesity, inappropriate activation of RAAS modulates insulin resistance, SNS activation, dysfunctional immunity and abnormal renal sodium handling, which collectively contribute to cardiovascular and renal dysfunction (Figure 1). ${ }^{40,78,84,108}$ In addition to the conventional circulating endocrine RAAS proteins, the heart, kidney, vasculature, adipose tissue, immune cells and brain express RAAS proteins as part of a tissue-specific local effect. ${ }^{98,149-152}$

Ang II synthesis by intravascular and intrarenal RAAS might directly regulate vascular stiffness, and endothelial and renal function. ${ }^{98,153}$ Ang II also modulates vascular and renal function by inhibiting metabolic insulin signalling and enhancing ERK1/2 and ET-1 signalling. ${ }^{84,104}$ Expression of RAAS components and increased expression and secretion of angiotensinogen by adipose tissue in obesity states supports a role for local RAAS activation in adipose tissue dysfunction. ${ }^{152}$ Moreover, increased Ang II production by perivascular adipose tissue contributes to impaired vascular function. ${ }^{154}$ This concept is further supported by studies in mice with an adipocyte-specific angiotensin knockout. When fed a high-fat diet, these mice have a lower blood pressure than wild-type control mice on an identical diet. 155

Circulating aldosterone might also be involved in the development of hypertension in individuals with obesity. Obesity can be accompanied by elevated plasma aldosterone levels ${ }^{156}$ and soluble factors derived from adipose tissue stimulate adrenal aldosterone secretion. ${ }^{157-159}$ Endothelial dysfunction ${ }^{160}$ and enhanced vascular smooth muscle reactivity have both been implicated in the modulation of vascular remodelling by aldosterone. ${ }^{98}$ Patients with primary hyperaldosteronism can be insulin-resistant, and aldosterone levels have been correlated with BMI and insulin resistance in patients with obesity who are normotensive. ${ }^{161}$ The precise role of aldosterone-induced vascular insulin resistance has not been fully elucidated; however, suppression of local inflammation and vascular stiffness by the mineralocorticoid antagonist spironolactone in rodent models of hypertension and insulin resistance has been reported. ${ }^{98,162}$ Aldosterone activates nicotinamide adenine dinucleotide phosphate-oxidase (NADPH), which promotes oxidative 
stress and decreases NO bio-availability. ${ }^{163}$ Aldosterone also increases endothelial stiffness by modulating epithelial sodium channel expression on the endothelial cell surface and NO release. ${ }^{163}$ Spironolactone can lower blood pressure in patients with obesity with elevated plasma aldosterone levels, although insulin resistance is unchanged in these patients. ${ }^{161,164}$ Mineralocorticoid receptor antagonists might improve insulin resistance in patients with hyperaldosteronism in contrast to individuals with obesity in whom aldosterone levels are only moderately elevated. ${ }^{164}$ However, insulin resistance in obesity can also develop via other pathways, including through the effects of overnutrition and SNS overactivation, meaning that mineralocorticoid receptor antagonists might not be appropriate in this context. ${ }^{40,165}$ In this regard, eplerenone, a drug with higher binding specificity for the mineralocorticoid receptor than spironolactone, improved flow-mediated dilation in healthy individuals 55-79 years old. ${ }^{166}$ Moreover, impaired endothelial function was improved in obese mice or exogenous-aldosterone-infused lean mice with an endothelial-specific mineralocorticoid receptor deletion. ${ }^{167}$ A subset of individuals with obesity and hypertension might also have insulin-resistance-related hyperaldosteronism, for which mineralocorticoid receptor inhibitors might be useful to treat. ${ }^{168}$

Attenuation of Ang II-induced vascular damage by mineralocorticoid receptor antagonists suggests a crosstalk between the Ang II and aldosterone signalling pathways. ${ }^{84,169}$ For example, Ang II-induced vascular smooth muscle contraction and hypertension are reduced in mice with a deletion of mineralocorticoid receptor specific to smooth muscle cells. ${ }^{148}$ This study also suggests mineralocorticoid receptor-regulated blood pressure is independent of hypertension induced by renal mechanisms. Both the direct beneficial effects of mineralocorticoid receptor antagonists, and their role in reducing Ang II-induced pathology support the adjunctive use of mineralocorticoid receptor antagonists to manage resistant hypertension in obesity. 29,38

\section{Immune and inflammatory mechanisms}

Accumulating evidence suggests that in patients with obesity, dysfunctional innate and adaptive immune and inflammatory responses contribute to vascular dysfunction and the pathogenesis of hypertension. However, the mechanisms and mediators of this relationship are still not well understood. Immune-mediated injury in obesity and hypertension can occur in the vasculature, central nervous system, kidney and adipose tissue, including perivascular tissue (Figure 1). ${ }^{112,170,171}$

Innate immunity-Macrophage infiltration into adipose tissue is associated with systemic insulin resistance. ${ }^{172}$ Distinct macrophage phenotypes elicit either a proinflammatory (M1 macrophages) or an anti-inflammatory response (M2 macrophages). ${ }^{172}$ Lipid-filled foam cells are a type of activated M1 macrophage that secrete proinflammatory cytokines within the vascular wall. ${ }^{173}$ Proinflammatory cytokines secreted by macrophages, such as TNF and IL-6, contribute to insulin resistance by activating kinases that phosphorylate serine residues of IRS-1 and IRS-2 and lead to suppression of metabolic insulin signalling and promotion of growth factor signalling in the vasculature. ${ }^{104}$ 
Adaptive immunity-Accumulating evidence suggest that T-cell activation and dysregulation of T-cell polarization can affect the pathophysiology of hypertension. T helper $\left(\mathrm{T}_{\mathrm{H}}\right) 1$ cells mediate the proinflammatory response and oxidative stress, and promote infiltration of M1 macrophages into adipose and vascular tissues. ${ }^{171} \mathrm{~T}_{\mathrm{H}} 17$ cells secrete IL-17, which contributes to vascular injury in hypertension. ${ }^{174} \mathrm{CD} 8^{+}$cells that are cytotoxic to the kidney and vasculature in hypertension also secrete IL-17. ${ }^{112} \mathrm{~T}$ regulatory cells $\left(\mathrm{T}_{\mathrm{REG}}\right.$ ) are a unique subpopulation of $\mathrm{T}$ cells ${ }^{40}$ that suppress proinflammatory $\mathrm{T}$-cell responses and promote polarization of M2 macrophages, which in turn leads to an antiinflammatory response. Insulin resistance and impaired vascular reactivity are associated with depletion of $\mathrm{T}_{\mathrm{REG}}$ cells and insulin sensitivity can be restored by $\mathrm{T}_{\mathrm{REG}}$-cell transfer and/or induction in rodents. ${ }^{175} \mathrm{~T}_{\mathrm{REG}}$ cells can also protect against insulin resistance and hypertension via secretion of anti-inflammatory cytokines such as IL-10, which can limit impaired insulin signalling caused by proinflammatory cytokines. ${ }^{176}$ Moreover, IL-10 can inhibit NADPH-oxidase-mediated oxidative stress. ${ }^{177}$ Finally, in patients with T2DM, an increase in proinflammatory $\mathrm{T}$-cell ratio (that is, elevated levels of $\mathrm{T}_{\mathrm{H}} 17$ cells and a decrease in levels of $\mathrm{T}_{\mathrm{REG}}$ cells might contribute to vascular dysfunction thereby leading to hypertension. ${ }^{178}$

Inflammasome-Activation of the inflammasome by IL-1 $\beta$ might contribute to insulin resistance, ${ }^{179}$ which is a response observed after pathogen exposure or danger-associated signal activation. ${ }^{180,181}$ In obesity states, palmitate and ceramide lipid levels are elevated, which activates inflammasomes. ${ }^{180}$ When fed a high-fat diet, mice deficient in central inflammasome molecules fail to become insulin resistant, which is accompanied by suppression of immune and inflammatory responses. ${ }^{180,181}$ Mice fed a high-fructose diet become obese and develop hyperuricaemia, which is associated with inflammasome activation, suggesting that uric acid also contributes to an inflammasome response in obesity induced by a high-fructose diet. ${ }^{182}$

RAAS in the immune system-The role of RAAS-mediated immune cell activation in hypertensive states is supported by experiments in $\mathrm{Ragl}^{-/-}$mice, which have an absolute deficiency of T and B lymphocytes. ${ }^{183}$ Adoptive transfer of T cells (but not B cells) can restore normal blood pressure, endothelial dysfunction, vascular remodelling and reactive oxygen species production. ${ }^{183}$ Moreover, in rats, Ang II triggers the recruitment of $\mathrm{T}_{\mathrm{H}} 1$ cells to renal and cardiovascular tissues, which is prevented by inhibitors of $\mathrm{AT}_{1} \mathrm{R}^{40,112,171}$ Adoptive transfer of $\mathrm{T}_{\mathrm{REG}}$ cells before Ang II infusion can attenuate blood pressure increases and improve vascular stiffness and impaired vasodilatory responses in young C57BL6 mice. ${ }^{171}$ This improvement was associated with attenuation of infiltration of inflammatory monocytes, macrophages, and $\mathrm{T}_{\mathrm{H}} 1$ cells, suppression of Ang II-induced NADPH oxidase activity, reactive oxygen species production, interferon $\gamma$ (IFN)- $\gamma$, TNF, and IL-6 production, and an increase in IL-10 secretion. ${ }^{177}$ Similarly, adoptive transfer of $\mathrm{T}_{\mathrm{REG}}$ cells prevented aldosterone-induced vascular damage in vascular and renal tissues of young C57BL6 mice. ${ }^{184}$

RAAS-stimulated activation of the peripheral immune system-via the central nervous system — might also lead to immune-mediated hypertension in patients with obesity. ${ }^{185,186}$ 
Spleen and lymph nodes are extensively innervated by the SNS and norepinephrine also modulates T-cell activation. ${ }^{187,188}$ In rats, intracerebroventricular administration of Ang II modulates lymphocyte proliferation and spleen cytokine secretion, and sympathetic denervation in the spleen can abolish these effects of Ang II. ${ }^{189}$ These studies suggest that the modulation of blood pressure occurs via both peripheral and central immunomodulation in addition to the haemodynamic effects of RAAS.

\section{Dietary fructose and uric acid}

A high-fructose diet can lead to hyperuricaemia owing to decreased renal clearance, increased uric acid production by adipose tissue and increased hepatic production via the induction of fructokinase ${ }^{37}$ Interestingly, serum uric acid is independently associated with a non-dipping circadian pattern of blood pressure in patients with hypertension, ${ }^{190}$ and $24-\mathrm{h}$ ambulatory diastolic and daytime systolic blood pressure can be decreased by reducing serum uric acid levels with allopurinol. ${ }^{191}$ However, these findings need to be confirmed by large-scale epidemiological and interventional studies.

Adipocyte dysfunction, maladaptive immune and inflammatory response, inappropriate activation of RAAS and enhanced oxidative stress all contribute to uric-acid-mediated induction of cardiovascular and renal injury. ${ }^{57,192}$ Uric acid increased expression of monocyte chemoattractant protein-1, macrophage infiltration and adipose tissue proinflammatory responses in a murine model of CRS. ${ }^{193}$ Uric acid can also contribute to an inflammasome response in obesity induced by a high-fructose diet. ${ }^{192}$ Uric acid increases $\mathrm{AT}_{1} \mathrm{R}$ levels in the vasculature, thereby contributing to Ang II-mediated endothelial dysfunction and vascular inflammation. ${ }^{40}$ Uric acid can also lead to ischaemic renal injury owing to excess collagen deposition, increased macrophage infiltration and expression of osteopontin, ${ }^{194}$ elevated juxtaglomerular renin production and reduced NO levels in the macula densa. ${ }^{194}$ Ingestion of fructose can also increase salt and water resorption in the small intestine and kidney. Moreover, in rats, a high-fructose diet can induce synthesis of ET-1 leading to hypertension, which can be attenuated by administration of an ET-1 inhibitor. ${ }^{57,195}$

\section{Incretins and DPP-4}

Glucagon like peptide-1 (GLP-1) and glucose-dependent insulinotropic peptide are gutderived hormones that enhance glucose-stimulated insulin secretion and suppress glucagon release, thereby modulating postprandial and long-term glucose homeostasis. ${ }^{196}$ These incretins are rapidly degraded by the exopeptidase DPP-4, which circulates in the plasma and limits the half-life of these substrate hormones to $\sim 2$ min. ${ }^{196,197}$ DPP-4 secretion from adipose tissue and inhibition of insulin-mediated glucose uptake in adipose and muscle cells by DPP-4 suggests that this exopeptidase has direct effects on insulin resistance (Figure 1). ${ }^{198}$ In the past 10 years, DPP-4-resistant GLP-1 analogues (exenatide and liraglutide) and DPP-4 inhibitors (sitagliptin, vildagliptin, saxigliptin, linagliptin and alogliptin) have been approved in the USA for use in patients with T2DM to lower $\mathrm{HbA}_{1 \mathrm{c}}$ levels. Augmentation of GLP-1 levels using these drugs can improve cardiovascular outcomes in patients with T2DM, ${ }^{196,197}$ suggesting that their effect extends beyond glycaemic control. Liraglutide and DPP-4 inhibitors can lower blood pressure in animal models of obesity and hypertension and 
in humans with T2DM. ${ }^{29,199,200}$ Linagliptin also has potent vasodilatory effects in ex vivo vascular ring preparations. ${ }^{201}$ DPP-4 substrates other than GLP-1, such as stromal cell derived factor $1 \mathrm{a}$ and the natriuretic peptides, ${ }^{202}$ might also contribute to the beneficial effect of DPP-4 inhibitors in the vasculature. Natriuretic peptide levels are low in patients with obesity ${ }^{203}$ and, therefore, DPP-4 inhibitors might be used to extend the bioavailability of these proteins.

DPP-4 is also widely expressed in the kidney and CD4 ${ }^{+}$and CD8 ${ }^{+}$immune cells. ${ }^{196,204}$ DPP-4 inhibitors can reduce the accumulation of M1 macrophages and increase levels of M2 macrophages in adipose tissue or atherosclerotic lesions. ${ }^{205,206}$ Moreover, GLP-1 can enhance $\mathrm{T}_{\mathrm{REG}^{-} \text {-cell function. }}{ }^{207} \mathrm{DPP}-4$ inhibitors might, therefore, be useful to treat immune-mediated mechanisms of hypertension in obesity.

\section{Estrogen}

In premenopausal women, estrogens can lower the risk of CVD; however, this cardioprotective effect is lost in premenopausal women who have obesity and diabetes mellitus. ${ }^{1,208-210}$ Differences in sympathetic-adrenal nervous system regulation between men and women suggest that premenopausal women might have better control of stimuli that activate the SNS than men and are consequently protected from development of arterial hypertension, which correlates with results seen in lean hypertensive rats. ${ }^{211-213}$ In these female patients, arterial stiffness is substantially higher than in age-matched men, which might explain why obesity limits the cardiovascular protection of estradiol in premenopausal women who have obesity. ${ }^{214-216}$ Estrogen receptor- $\alpha$ and GPR-30 can also increase $\mathrm{T}_{\mathrm{REG}^{-}}$ cell function, ${ }^{217}$ and insulin sensitivity is modulated by signalling mediated by estrogen receptor $a$ in macrophages. ${ }^{218}$ Whether these immune functions of $\mathrm{T}_{\mathrm{REG}}$ cells and macrophages are modulated in premenopausal women who have obesity remains to be determined.

Estrogen modulates Ang II signalling differently under normal and high-salt diets. For example, estradiol suppresses Ang II signalling by reducing $\mathrm{AT}_{1} \mathrm{R}$ expression, ${ }^{98,219}$ whereas GPR-30 increases the expression of angiotensin converting enzyme (ACE) 2, decreasing $\mathrm{AT}_{1} \mathrm{R}$ expression. ${ }^{220,221}$ By contrast, estradiol can increase $\mathrm{AT}_{1} \mathrm{R}$ expression when NO synthase is inhibited and under high-salt conditions, ${ }^{222}$ which suggests that preventing estrogen suppression of Ang II signalling might decrease cardiovascular risk in women who have obesity. In the Framingham study, aldosterone levels were higher in women than in men, and were positively associated with markers of cardiac remodelling, such as left ventricular wall thickness in women but not in men. ${ }^{210}$ These findings suggest that crosstalk between estrogen and mineralocorticoid receptors might contribute to altered immune and inflammatory responses, endothelial dysfunction and arterial stiffness relating to obesity and hypertension in women.

\section{Therapeutics}

Lifestyle modifications, including calorie restriction and exercise, are effective in limiting the effect of obesity on hypertension (Figure 2). However, many patients find weight loss programs difficult to maintain and high dropout rates occur during the initial years of such 
programs. ${ }^{223}$ Pharmacologic interventions are, therefore, useful when patients who have obesity are unable to comply with their weight reduction program or when weight reduction measures alone cannot reduce hypertension (Figure 2).

Targeting RAAS can potentially improve multiple pathophysiological components of obesity-associated hypertension, including increasing GLP-1 levels and modulating SGLT2 or SNS overactivation. ${ }^{29,38,223}$ The angiotensin receptor inhibitor losartan can reduce serum uric acid levels, but a similar effect has not been seen with other such blockers. ${ }^{224}$ DPP-4 inhibitors and GLP-1 analogues might also be used to manage hypertension as an add-on therapy in patients with T2DM. ${ }^{29}$ Owing to the complex pathophysiology of treatmentresistant hypertension, the correct management of hypertension in patients who have obesity is of major concern to clinicians. ${ }^{225}$ Aldosterone antagonists and control of inappropriate SNS activation by renal denervation are emerging as new modalities for the management of treatment-resistant hypertension (Figure 2). 7,40,226

\section{Conclusions}

Hypertension related to obesity can occur via multiple mechanisms: insulin resistance; adipokine alterations; inappropriate SNS and RAAS activation; structural and functional abnormalities in the kidney, heart and vasculature; and maladaptive immunity.

Hyperuricaemia associated with a high-fructose diet also contributes to vascular dysfunction, renal injury and immune activation. DPP-4-mediated incretin signalling can affect vascular function, immune responses and natriuresis in obesity states. Estrogenmediated insulin sensitivity in premenopausal women who do not have obesity is compromised when they develop obesity. Alteration in the gut microbiome in obesity is another factor that contributes to insulin resistance and dysfunctional immunity. Treatmentresistant hypertension is more common in individuals with obesity than in those who do not have obesity, especially in patients with OSA, and is a major challenge in the management of hypertension. Adjunctive therapy with mineralocorticoid receptor antagonists and renal denervation are emerging as therapeutic measures to control treatment-resistant hypertension. Therapeutic strategies targeting obesity-associated hypertension are needed mineralocorticoid receptor antagonists are especially promising in this context. ${ }^{7,29}$ More studies focused on the clinical utility of treating hypertension in children with obesity are also necessary. Despite the positive therapeutic developments, obesity-related treatmentresistant hypertension remains a major issue in health care.

\section{Acknowledgments}

This work was supported by grants from the NIH (R01 HL73101-01A1 and R01 HL107910-01) and Veterans Affairs Merit System (0018) to J.R.S. and by an investigator-initiated grant from Boehringer Ingelheim Pharmaceuticals to V.G.D.

\section{References}

1. Malik VS, Willett WC, Hu FB. Global obesity: trends, risk factors and policy implications. Nat Rev Endocrinol. 2013; 9:13-27. [PubMed: 23165161] 
2. Thomsen BL, Ekstrøm CT, Sørensen TI. Development of the obesity epidemic in Denmark: cohort, time and age effects among boys born 1930-1975. Int J Obes Relat Metab Disord. 1999; 23:693701. [PubMed: 10454102]

3. Heimburger DC, et al. A festschrift for Roland L. Weinsier: nutrition scientist, educator, and clinician. Obes Res. 2003; 11:1246-1262. [PubMed: 14569051]

4. Keith SW, et al. Putative contributors to the secular increase in obesity: exploring the roads less traveled. Int J Obes (Lond). 2006; 30:1585-1594. [PubMed: 16801930]

5. McAllister EJ, et al. Ten putative contributors to the obesity epidemic. Crit Rev Food Sci Nutr. 2009; 49:868-913. [PubMed: 19960394]

6. Sørensen TI. Conference on "Multidisciplinary approaches to nutritional problems". Symposium on "Diabetes and health" Challenges in the study of causation of obesity. Proc Nutr Soc. 2009; 68:4354. [PubMed: 19079823]

7. Sowers JR. Diabetes mellitus and vascular disease. Hypertension. 2013; 61:943-947. [PubMed: 23595139]

8. Flegal KM, Carroll MD, Ogden CL, Curtin LR. Prevalence and trends in obesity among US adults, 1999-2008. JAMA. 2010; 303:235-241. [PubMed: 20071471]

9. Ogden CL, et al. Prevalence of overweight and obesity in the United States, 1999-2004. JAMA. 2006; 295:1549-1555. [PubMed: 16595758]

10. Sowers JR, Whaley-Connel AT, Hayden MR. The role of overweight and obesity in the cardiorenal syndrome. Cardiorenal Med. 2011; 1:5-12. [PubMed: 22258461]

11. Yach D, Stuckler D, Brownell KD. Epidemiologic and economic consequences of the global epidemics of obesity and diabetes. Nat Med. 2006; 12:62-66. [PubMed: 16397571]

12. Kannel WB, Brand N, Skinner JJ Jr, Dawber TR, McNamara PM. The relation of adiposity to blood pressure and development of hypertension The Framingham study. Ann Intern Med. 1967; 67:48-59. [PubMed: 6028658]

13. Bramlage $P$, et al. Hypertension in overweight and obese primary care patients is highly prevalent and poorly controlled. Am J Hypertens. 2004; 17:904-910. [PubMed: 15485752]

14. Krauss RM, Winston M, Fletcher BJ, Grundy SM. Obesity: impact on cardiovascular disease. Circulation. 1998; 98:1472-1476.

15. Garrison RJ, Kannel WB, Stokes J 3rd, Castelli WP. Incidence and precursors of hypertension in young adults: the Framingham Offspring Study. Prev Med. 1987; 16:235-251. [PubMed: 3588564]

16. Brown $\mathrm{CD}$, et al. Body mass index and the prevalence of hypertension and dyslipidemia. Obes Res. 2000; 8:605-619. [PubMed: 11225709]

17. Shihab HM, et al. Body mass index and risk of incident hypertension over the life course: the Johns Hopkins Precursors Study. Circulation. 2012; 126:2983-2989. [PubMed: 23151344]

18. Droyvold WB, Midthjell K, Nilsen TI, Holmen J. Change in body mass index and its impact on blood pressure: a prospective population study. Int J Obes (Lond). 2005; 29:650-655. [PubMed: 15809666]

19. Vague J. The degree of masculine differentiation of obesities: a factor determining predisposition to diabetes, atherosclerosis, gout, and uric calculous disease. Am J Clin Nutr. 1956; 4:20-34. [PubMed: 13282851]

20. Kissebah AH, et al. Relation of body fat distribution to metabolic complications of obesity. J Clin Endocrinol Metab. 1982; 54:254-260. [PubMed: 7033275]

21. Krotkiewski M, Björntorp P, Sjöström L, Smith U. Impact of obesity on metabolism in men and women. Importance of regional adipose tissue distribution. J Clin Invest. 1983; 72:1150-1162. [PubMed: 6350364]

22. Cassano PA, Segal MR, Vokonas PS, Weiss ST. Body fat distribution, blood pressure, and hypertension. A prospective cohort study of men in the normative aging study. Ann Epidemiol. 1990; 1:33-48. [PubMed: 1669488]

23. Lapidus L, et al. Distribution of adipose tissue and risk of cardiovascular disease and death: a 12 year follow up of participants in the population study of women in Gothenburg, Sweden. Br Med J (Clin Res Ed). 1984; 289:1257-1261. 
24. Larsson B, et al. Abdominal adipose tissue distribution, obesity, and risk of cardiovascular disease and death: 13 year follow up of participants in the study of men born in 1913. Br Med J (Clin Res Ed). 1984; 288:1401-1404.

25. Alberti KG, Zimmet PZ. Definition, diagnosis and classification of diabetes mellitus and its complications. Part 1: diagnosis and classification of diabetes mellitus provisional report of a WHO consultation. Diabet Med. 1998; 15:539-553. [PubMed: 9686693]

26. Alberti KG, et al. Harmonizing the metabolic syndrome. A joint interim statement of the International Diabetes Federation Task Force on Epidemiology and Prevention; National Heart, Lung, and Blood Institute; American Heart Association; World Heart Federation; International Atherosclerosis Society; and International Association for the Study of Obesity. Circulation. 2009; 120:1640-1645. [PubMed: 19805654]

27. Neter JE, Stam BE, Kok FJ, Grobbee DE, Geleijnse JM. Influence of weight reduction on blood pressure: a meta-analysis of randomized controlled trials. Hypertension. 2003; 42:878-884. [PubMed: 12975389]

28. Appel LJ, et al. Dietary approaches to prevent and treat hypertension: a scientific statement from the American Heart Association. Hypertension. 2006; 47:296-308. [PubMed: 16434724]

29. Landsberg L, et al. Obesity-related hypertension: pathogenesis, cardiovascular risk, and treatment - a position paper of the The Obesity Society and The American Society of Hypertension. Obesity (Silver Spring). 2013; 21:8-24. [PubMed: 23401272]

30. Kotchen TA. Obesity-related hypertension: epidemiology, pathophysiology, and clinical management. Am J Hypertens. 2010; 23:1170-1178. [PubMed: 20706196]

31. Esler M, et al. Mechanisms of sympathetic activation in obesity-related hypertension. Hypertension. 2006; 48:787-796. [PubMed: 17000932]

32. Henry SL, et al. Developmental origins of obesity-related hypertension. Clin Exp Pharmacol Physiol. 2012; 39:799-806. [PubMed: 21801195]

33. Rumantir MS, et al. Neural mechanisms in human obesity-related hypertension. J Hypertens. 1999; 17:1125-1133. [PubMed: 10466468]

34. Grassi G, et al. Adrenergic and reflex abnormalities in obesity-related hypertension. Hypertension. 2000; 36:538-542. [PubMed: 11040232]

35. Zhao D, et al. Dietary factors associated with hypertension. Nat Rev Cardiol. 2011; 8:456-465. [PubMed: 21727918]

36. Aghamohammadzadeh R, Heagerty AM. Obesity-related hypertension: epidemiology, pathophysiology, treatments, and the contribution of perivascular adipose tissue. Ann Med. 2012; 44(Suppl 1):S74-S84. [PubMed: 22713152]

37. Johnson RJ, et al. Sugar, uric acid, and the etiology of diabetes and obesity. Diabetes. 2013; 62:3307-3315. [PubMed: 24065788]

38. Jordan J, et al. Joint statement of the European Association for the Study of Obesity and the European Society of Hypertension: obesity and difficult to treat arterial hypertension. J Hypertens. 2012; 30:1047-1055. [PubMed: 22573071]

39. Messerli FH, et al. Disparate cardiovascular findings in men and women with essential hypertension. Ann Intern Med. 1987; 107:158-161. [PubMed: 3605894]

40. Aroor AR, McKarns S, Demarco VG, Jia G, Sowers JR. Maladaptive immune and inflammatory pathways lead to cardiovascular insulin resistance. Metabolism. 2013; 62:1543-1552. [PubMed: 23932846]

41. Huxley R, Barzi F, Woodward M. Excess risk of fatal coronary heart disease associated with diabetes in men and women: meta-analysis of 37 prospective cohort studies. BMJ. 2006; 332:7378. [PubMed: 16371403]

42. Barrett-Connor E, et al. Women and heart disease: the role of diabetes and hyperglycemia. Arch Intern Med. 2004; 164:934-942. [PubMed: 15136300]

43. Howard BV, et al. Adverse effects of diabetes on multiple cardiovascular disease risk factors in women. The Strong Heart Study. Diabetes Care. 1998; 21:1258-1265. [PubMed: 9702430]

44. Okosun IS, Prewitt TE, Cooper RS. Abdominal obesity in the United States: prevalence and attributable risk of hypertension. J Hum Hypertens. 1999; 13:425-430. [PubMed: 10449204] 
45. Huang Z, et al. Body weight, weight change, and risk for hypertension in women. Ann Intern Med. 1998; 128:81-88. [PubMed: 9441586]

46. Engeli S, et al. Weight loss and the renin-angiotensin-aldosterone system. Hypertension. 2005; 45:356-362. [PubMed: 15630041]

47. Li M, Sloboda DM, Vickers MH. Maternal obesity and developmental programming of metabolic disorders in offspring: evidence from animal models. Exp Diabetes Res. 2011; 2011:592408. [PubMed: 21969822]

48. Fullston T, et al. Paternal obesity initiates metabolic disturbances in two generations of mice with incomplete penetrance to the F2 generation and alters the transcriptional profile of testis and sperm microRNA content. FASEB J. 2013; 27:4226-4243. [PubMed: 23845863]

49. Bray GA, Nielsen SJ, Popkin BM. Consumption of high-fructose corn syrup in beverages may play a role in the epidemic of obesity. Am J Clin Nutr. 2004; 79:537-543. [PubMed: 15051594]

50. Khitan Z, Kim DH. Fructose: a key factor in the development of metabolic syndrome and hypertension. J Nutr Metab. 2013; 2013:682673. [PubMed: 23762544]

51. Hallfrisch J. Metabolic effects of dietary fructose. FASEB J. 1990; 4:2652-2660. [PubMed: 2189777]

52. Nguyen S, Choi HK, Lustig RH, Hsu CY. Sugar-sweetened beverages, serum uric acid, and blood pressure in adolescents. J Pediatr. 2009; 154:807-813. [PubMed: 19375714]

53. D’Angelo G, Elmarakby AA, Pollock DM, Stepp DW. Fructose feeding increases insulin resistance but not blood pressure in Sprague-Dawley rats. Hypertension. 2005; 46:806-811. [PubMed: 16157789]

54. Vasdev S, Gill V, Parai S, Gadag V. Fructose-induced hypertension in Wistar-Kyoto rats: interaction with moderately high dietary salt. Can J Physiol Pharmacol. 2007; 85:413-421. [PubMed: 17612650]

55. Tapia E, et al. Synergistic effect of uricase blockade plus physiological amounts of fructoseglucose on glomerular hypertension and oxidative stress in rats. Am J Physiol Renal Physiol. 2013; 304:F727-F736. [PubMed: 23303409]

56. Weisbrod RM, et al. Arterial stiffening precedes systolic hypertension in diet-induced obesity. Hypertension. 2013; 62:1105-1110. [PubMed: 24060894]

57. Madero M, Perez-Pozo SE, Jalal D, Johnson RJ, Sanchez-Lozada LG. Dietary fructose and hypertension. Curr Hypertens Rep. 2011; 13:29-35. [PubMed: 20957458]

58. He FJ, MacGregor GA. Effect of modest salt reduction on blood pressure: a meta-analysis of randomized trials. Implications for public health. J Hum Hypertens. 2002; 16:761-770. [PubMed: 12444537]

59. Intersalt: an international study of electrolyte excretion and blood pressure. Results for 24 hour urinary sodium and potassium excretion. Intersalt Cooperative Research Group. BMJ. 1988; 297:319-328. No authors listed. [PubMed: 3416162]

60. Simopoulos AP. The importance of the ratio of omega-6/omega-3 essential fatty acids. Biomed Pharmacother. 2002; 56:365-379. [PubMed: 12442909]

61. Morris MC, Sacks F, Rosner B. Does fish oil lower blood pressure? A meta-analysis of controlled trials. Circulation. 1993; 88:523-533. [PubMed: 8339414]

62. Appel LJ, Miller ER 3rd, Seidler AJ, Whelton PK. Does supplementation of diet with 'fish oil' reduce blood pressure? A meta-analysis of controlled clinical trials. Arch Intern Med. 1993; 153:1429-1438. [PubMed: 8141868]

63. Hu FB, Manson JE. Omega-3 fatty acids and secondary prevention of cardiovascular disease-is it just a fish tale?: comment on "Efficacy of omega-3 fatty acid supplements (eicosapentaenoic acid and docosahexaenoic acid) in the secondary prevention of cardiovascular disease". Arch Intern Med. 2012; 172:694-696. [PubMed: 22493410]

64. Appel LJ, et al. A clinical trial of the effects of dietary patterns on blood pressure. DASH Collaborative Research Group. N Engl J Med. 1997; 336:1117-1124. [PubMed: 9099655]

65. Hord NG, Tang Y, Bryan NS. Food sources of nitrates and nitrites: the physiologic context for potential health benefits. Am J Clin Nutr. 2009; 90:1-10. [PubMed: 19439460]

66. Coles LT, Clifton PM. Effect of beetroot juice on lowering blood pressure in free-living, diseasefree adults: a randomized, placebo-controlled trial. Nutr J. 2012; 11:106. [PubMed: 23231777] 
67. Siervo M, Lara J, Ogbonmwan I, Mathers JC. Inorganic nitrate and beetroot juice supplementation reduces blood pressure in adults: a systematic review and meta-analysis. J Nutr. 2013; 143:818826. [PubMed: 23596162]

68. Moncada S, Palmer RM, Higgs EA. Nitric oxide: physiology, pathophysiology, and pharmacology. Pharmacol Rev. 1991; 43:109-142. [PubMed: 1852778]

69. Harris K, Kassis A, Major G, Chou CJ. Is the gut microbiota a new factor contributing to obesity and its metabolic disorders? J Obes. 2012; 2012:879151. [PubMed: 22315672]

70. Tilg H, Kaser A. Gut microbiome, obesity, and metabolic dysfunction. J Clin Invest. 2011; 121:2126-2132. [PubMed: 21633181]

71. Turnbaugh PJ, et al. An obesity-associated gut microbiome with increased capacity for energy harvest. Nature. 2006; 444:1027-1031. [PubMed: 17183312]

72. Ley RE, et al. Obesity alters gut microbial ecology. Proc Natl Acad Sci USA. 2005; 102:1107011075. [PubMed: 16033867]

73. Geurts L, et al. Altered gut microbiota and endocannabinoid system tone in obese and diabetic leptin-resistant mice: impact on apelin regulation in adipose tissue. Front Microbiol. 2011; 2:149. [PubMed: 21808634]

74. Murphy EF, et al. Composition and energy harvesting capacity of the gut microbiota: relationship to diet, obesity and time in mouse models. Gut. 2010; 59:1635-1642. [PubMed: 20926643]

75. Shen J, Obin MS, Zhao L. The gut microbiota, obesity and insulin resistance. Mol Aspects Med. 2013; 34:39-58. [PubMed: 23159341]

76. Kootte RS, et al. The therapeutic potential of manipulating gut microbiota in obesity and type 2 diabetes mellitus. Diabetes Obes Metab. 2012; 14:112-120. [PubMed: 21812894]

77. Delzenne NM, Neyrinck AM, Backhed F, Cani PD. Targeting gut microbiota in obesity: effects of prebiotics and probiotics. Nat Rev Endocrinol. 2011; 7:639-646. [PubMed: 21826100]

78. Kurukulasuriya LR, Stas S, Lastra G, Manrique C, Sowers JR. Hypertension in obesity. Med Clin North Am. 2011; 95:903-917. [PubMed: 21855699]

79. Slomko H, Heo HJ, Einstein FH. Minireview: Epigenetics of obesity and diabetes in humans. Endocrinology. 2012; 153:1025-1030. [PubMed: 22253427]

80. Sharma AM. Is there a rationale for angiotensin blockade in the management of obesity hypertension? Hypertension. 2004; 44:12-19. [PubMed: 15173127]

81. Messerli FH, et al. Obesity and essential hypertension. Hemodynamics, intravascular volume, sodium excretion, and plasma renin activity. Arch Intern Med. 1981; 141:81-85. [PubMed: 7004372]

82. Strazzullo P, et al. Altered renal sodium handling in men with abdominal adiposity: a link to hypertension. J Hypertens. 2001; 19:2157-2164. [PubMed: 11725158]

83. McCurley A, et al. Direct regulation of blood pressure by smooth muscle cell mineralocorticoid receptors. Nat Med. 2012; 18:1429-1433. [PubMed: 22922412]

84. Bender SB, McGraw AP, Jaffe IZ, Sowers JR. Mineralocorticoid receptor-mediated vascular insulin resistance: an early contributor to diabetes-related vascular disease? Diabetes. 2013; 62:313-319. [PubMed: 23349535]

85. Hayden MR, Tyagi SC. Uric acid: A new look at an old risk marker for cardiovascular disease, metabolic syndrome, and type 2 diabetes mellitus: The urate redox shuttle. Nutr Metab (Lond). 2004; 1:10. [PubMed: 15507132]

86. Zhong J, Rao X, Rajagopalan S. An emerging role of dipeptidyl peptidase 4 (DPP4) beyond glucose control: potential implications in cardiovascular disease. Atherosclerosis. 2013; 226:305314. [PubMed: 23083681]

87. Schleithoff C, Voelter-Mahlknecht S, Dahmke IN, Mahlknecht U. On the epigenetics of vascular regulation and disease. Clin Epigenetics. 2012; 4:7. [PubMed: 22621747]

88. Ordovas JM, Smith CE. Epigenetics and cardiovascular disease. Nat Rev Cardiol. 2010; 7:510519. [PubMed: 20603647]

89. Ortega FJ, et al. Targeting the circulating microRNA signature of obesity. Clin Chem. 2013; 59:781-792. [PubMed: 23396142] 
90. Williams MD, Mitchell GM. MicroRNAs in insulin resistance and obesity. Exp Diabetes Res. 2012; 2012:484696. [PubMed: 22851965]

91. Nistala R, et al. Prenatal programming and epigenetics in the genesis of the cardiorenal syndrome. Cardiorenal Med. 2011; 1:243-254. [PubMed: 22096456]

92. Ganu RS, Harris RA, Collins K, Aagaard KM. Early origins of adult disease: approaches for investigating the programmable epigenome in humans, nonhuman primates, and rodents. ILAR J. 2012; 53:306-321. [PubMed: 23744969]

93. Barker DJ. Intrauterine programming of adult disease. Mol Med Today. 1995; 1:418-423. [PubMed: 9415190]

94. Gillman MW. Developmental origins of health and disease. N Engl J Med. 2005; 353:1848-1850. [PubMed: 16251542]

95. Femia R, et al. Carotid intima-media thickness in confirmed prehypertensive subjects: predictors and progression. Arterioscler Thromb Vasc Biol. 2007; 27:2244-2249. [PubMed: 17656672]

96. Cavalcante JL, Lima JA, Redheuil A, Al-Mallah MH. Aortic stiffness: current understanding and future directions. J Am Coll Cardiol. 2011; 57:1511-1522. [PubMed: 21453829]

97. Liao D, et al. Arterial stiffness and the development of hypertension. The ARIC study. Hypertension. 1999; 34:201-206. [PubMed: 10454441]

98. Aroor AR, et al. The role of tissue renin-angiotensin-aldosterone system in the development of endothelial dysfunction and arterial stiffness. Front Endocrinol. 2013; 4:161.

99. Stenmark KR, et al. The adventitia: essential regulator of vascular wall structure and function. Ann Rev Physiol. 2013; 75:23-47. [PubMed: 23216413]

100. Sehgel NL, et al. Increased vascular smooth muscle cell stiffness; a novel mechanism for aortic stiffness in hypertension. Am J Physiol Heart Circ Physiol. 2013; 305:H1281-H1287. [PubMed: 23709594]

101. Sandoo A, van Zanten JJ, Metsios GS, Carroll D, Kitas GD. The endothelium and its role in regulating vascular tone. Open Cardiovasc Med J. 2010; 4:302-312. [PubMed: 21339899]

102. Li R, et al. Vascular insulin resistance in prehypertensive rats: role of PI3-kinase/Akt/ eNOS signaling. Eur J Pharmacol. 2010; 628:140-147. [PubMed: 19944677]

103. Muniyappa R, Sowers JR. Role of insulin resistance in endothelial dysfunction. Rev Endocr Metab Disord. 2013; 14:5-12. [PubMed: 23306778]

104. Aroor AR, Mandavia CH, Sowers JR. Insulin resistance and heart failure: molecular mechanisms. Heart Fail Clin. 2012; 8:609-617. [PubMed: 22999243]

105. Brillante DG, O'Sullivan AJ, Howes LG. Arterial stiffness in insulin resistance: the role of nitric oxide and angiotensin II receptors. Vasc Health Risk Manag. 2009; 5:73-78. [PubMed: 19436651]

106. DeMarco VG, Johnson MS, Whaley-Connell AT, Sowers JR. Cytokine abnormalities in the etiology of the cardiometabolic syndrome. Curr Hypertens Rep. 2010; 12:93-98. [PubMed: 20424939]

107. de Leal VO, Mafra D. Adipokines in obesity. Clin Chim Acta. 2013; 419:87-94. [PubMed: 23422739]

108. Dorresteijn JA, Visseren FL, Spiering W. Mechanisms linking obesity to hypertension. Obes Rev. 2012; 13:17-26. [PubMed: 21831233]

109. Brown NJ. Contribution of aldosterone to cardiovascular and renal inflammation and fibrosis. Nat Rev Nephrol. 2013; 9:459-469. [PubMed: 23774812]

110. Johnson RJ, Rodriguez-Iturbe B, Kang DH, Feig DI, Herrera-Acosta J. A unifying pathway for essential hypertension. Am J Hypertens. 2005; 18:431-440. [PubMed: 15797666]

111. Montecucco F, Pende A, Quercioli A, Mach F. Inflammation in the pathophysiology of essential hypertension. J Nephrol. 2011; 24:23-34. [PubMed: 20437401]

112. Harrison DG, Marvar PJ, Titze JM. Vascular inflammatory cells in hypertension. Front Physiol. 2012; 3:128. [PubMed: 22586409]

113. DeFronzo RA, Davidson JA, Del Prato S. The role of the kidneys in glucose homeostasis: a new path towards normalizing glycaemia. Diabetes Obes Metab. 2012; 14:5-14. [PubMed: 21955459] 
114. Kanai Y, Lee WS, You G, Brown D, Hediger MA. The human kidney low affinity $\mathrm{Na}^{+} /$glucose cotransporter SGLT2. Delineation of the major renal reabsorptive mechanism for D-glucose. J Clin Invest. 1994; 93:397-404. [PubMed: 8282810]

115. Rahmoune $\mathrm{H}$, et al. Glucose transporters in human renal proximal tubular cells isolated from the urine of patients with non-insulin-dependent diabetes. Diabetes. 2005; 54:3427-3434. [PubMed: 16306358]

116. Tabatabai NM, Sharma M, Blumenthal SS, Petering DH. Enhanced expressions of sodiumglucose cotransporters in the kidneys of diabetic Zucker rats. Diabetes Res Clin Pract. 2009; 83:e27-e30. [PubMed: 19095325]

117. Vallon V, et al. Knockout of Na-glucose transporter SGLT2 attenuates hyperglycemia and glomerular hyperfiltration but not kidney growth or injury in diabetes mellitus. Am J Physiol Renal Physiol. 2013; 304:F156-F167. [PubMed: 23152292]

118. Vallon V, Richter K, Blantz RC, Thomson S, Osswald H. Glomerular hyperfiltration in experimental diabetes mellitus: potential role of tubular reabsorption. J Am Soc Nephrol. 1999; 10:2569-2576. [PubMed: 10589696]

119. Lee YJ, Lee YJ, Han HJ. Regulatory mechanisms of $\mathrm{Na}(+) /$ glucose cotransporters in renal proximal tubule cells. Kidney Int Suppl. 2007; 106:S27-S35. [PubMed: 17653207]

120. Bautista R, et al. Angiotensin II-dependent increased expression of $\mathrm{Na}^{+}$-glucose cotransporter in hypertension. Am J Physiol Renal Physiol. 2004; 286:F127-F133. [PubMed: 14506074]

121. Ghezzi C, Wright EM. Regulation of the human $\mathrm{Na}^{+}$-dependent glucose cotransporter hSGLT2. Am J Physiol Cell Physiol. 2012; 303:C348-C354. [PubMed: 22673616]

122. Ferrannini E, Ramos SJ, Salsali A, Tang W, List JF. Dapagliflozin monotherapy in type 2 diabetic patients with inadequate glycemic control by diet and exercise: a randomized, double-blind, placebo-controlled, phase 3 trial. Diabetes Care. 2010; 33:2217-2224. [PubMed: 20566676]

123. Bailey CJ, Gross JL, Pieters A, Bastien A, List JF. Effect of dapagliflozin in patients with type 2 diabetes who have inadequate glycaemic control with metformin: a randomised, double-blind, placebo-controlled trial. Lancet. 2010; 375:2223-2233. [PubMed: 20609968]

124. Nauck MA, et al. Dapagliflozin versus glipizide as add-on therapy in patients with type 2 diabetes who have inadequate glycemic control with metformin: a randomized, 52-week, double-blind, active-controlled noninferiority trial. Diabetes Care. 2011; 34:2015-2022. [PubMed: 21816980]

125. Hall JE, et al. Impact of the obesity epidemic on hypertension and renal disease. Curr Hypertens Rep. 2003; 5:386-392. [PubMed: 12948431]

126. O'Dea K, Esler M, Leonard P, Stockigt JR, Nestel P. Noradrenaline turnover during under- and over-eating in normal weight subjects. Metabolism. 1982; 31:896-899. [PubMed: 7121260]

127. Kassab S, et al. Renal denervation attenuates the sodium retention and hypertension associated with obesity. Hypertension. 1995; 25:893-897. [PubMed: 7721450]

128. Egan BM, Schork NJ, Weder AB. Regional hemodynamic abnormalities in overweight men. Focus on alpha-adrenergic vascular responses. Am J Hypertens. 1989; 2:428-434. [PubMed: 2547397]

129. Agapitov AV, Correia ML, Sinkey CA, Haynes WG. Dissociation between sympathetic nerve traffic and sympathetically mediated vascular tone in normotensive human obesity. Hypertension. 2008; 52:687-695. [PubMed: 18695151]

130. Lambert GW, Straznicky NE, Lambert EA, Dixon JB, Schlaich MP. Sympathetic nervous activation in obesity and the metabolic syndrome-causes, consequences and therapeutic implications. Pharmacol Ther. 2010; 126:159-172. [PubMed: 20171982]

131. Hall JE, et al. Obesity-induced hypertension: role of sympathetic nervous system, leptin, and melanocortins. J Biol Chem. 2010; 285:17271-17276. [PubMed: 20348094]

132. Lohmeier TE, Iliescu R. The sympathetic nervous system in obesity hypertension. Curr Hypertens Rep. 2013; 15:409-416. [PubMed: 23677623]

133. Sawicki PT, Baba T, Berger M, Starke A. Normal blood pressure in patients with insulinoma despite hyperinsulinemia and insulin resistance. J Am Soc Nephrol. 1992; 3:S64-S68. [PubMed: 1457762] 
134. Anderson EA, Hoffman RP, Balon TW, Sinkey CA, Mark AL. Hyperinsulinemia produces both sympathetic neural activation and vasodilation in normal humans. J Clin Invest. 1991; 87:22462252. [PubMed: 2040704]

135. Gao Q, et al. Disruption of neural signal transducer and activator of transcription 3 causes obesity, diabetes, infertility, and thermal dysregulation. Proc Natl Acad Sci USA. 2004; 101:4661-4666. [PubMed: 15070774]

136. Smith MM, Minson CT. Obesity and adipokines: effects on sympathetic overactivity. J Physiol. 2012; 590:1787-1801. [PubMed: 22351630]

137. Lurbe E, et al. Added impact of obesity and insulin resistance in nocturnal blood pressure elevation in children and adolescents. Hypertension. 2008; 51:635-641. [PubMed: 18195166]

138. Demarco VG, et al. Obesity-related alterations in cardiac lipid profile and nondipping blood pressure pattern during transition to diastolic dysfunction in male $\mathrm{db} / \mathrm{db}$ mice. Endocrinology. 2013; 154:159-171. [PubMed: 23142808]

139. Ohkubo T, et al. Prognostic significance of the nocturnal decline in blood pressure in individuals with and without high 24-h blood pressure: the Ohasama study. J Hypertens. 2002; 20:21832189. [PubMed: 12409956]

140. Dangardt F, et al. Reduced cardiac vagal activity in obese children and adolescents. Clin Physiol Funct Imaging. 2011; 31:108-113. [PubMed: 21087396]

141. Silverberg DS, Oksenberg A. Are sleep-related breathing disorders important contributing factors to the production of essential hypertension? Curr Hypertens Rep. 2001; 3:209-215. [PubMed: 11353571]

142. Logan AG, et al. High prevalence of unrecognized sleep apnoea in drug-resistant hypertension. $\mathbf{J}$ Hypertens. 2001; 19:2271-2277. [PubMed: 11725173]

143. Lavie P, Hoffstein V. Sleep apnea syndrome: a possible contributing factor to resistant. Sleep. 2001; 24:721-725. [PubMed: 11560187]

144. Grassi G, et al. Obstructive sleep apnea-dependent and -independent adrenergic activation in obesity. Hypertension. 2005; 46:321-325. [PubMed: 15983234]

145. Narkiewicz K, van de Borne PJ, Cooley RL, Dyken ME, Somers VK. Sympathetic activity in obese subjects with and without obstructive sleep apnea. Circulation. 1998; 98:772-776. [PubMed: 9727547]

146. Goodfriend TL, Calhoun DA. Resistant hypertension, obesity, sleep apnea, and aldosterone: theory and therapy. Hypertension. 2004; 43:518-524. [PubMed: 14732721]

147. Witkowski A, et al. Effects of renal sympathetic denervation on blood pressure, sleep apnea course, and glycemic control in patients with resistant hypertension and sleep apnea. Hypertension. 2011; 58:559-565. [PubMed: 21844482]

148. McCurley A, McGraw A, Pruthi D, Jaffe IZ. Smooth muscle cell mineralocorticoid receptors: role in vascular function and contribution to cardiovascular disease. Pflugers Arch. 2013; 465:1661-1670. [PubMed: 23636772]

149. Ruster C, Wolf G. The role of the renin-angiotensin-aldosterone system in obesity-related renal diseases. Semin Nephrol. 2013; 33:44-53. [PubMed: 23374893]

150. Hall JE, et al. Hypertension: physiology and pathophysiology. Compr Physiol. 2012; 2:23932442. [PubMed: 23720252]

151. Hayden MR, et al. Possible mechanisms of local tissue renin-angiotensin system activation in the cardiorenal metabolic syndrome and type 2 diabetes mellitus. Cardiorenal Med. 2011; 1:193210. [PubMed: 22096455]

152. Engeli S, Negrel R, Sharma AM. Physiology and pathophysiology of the adipose tissue reninangiotensin system. Hypertension. 2000; 35:1270-1277. [PubMed: 10856276]

153. Kumar R, Thomas CM, Yong QC, Chen W, Baker KM. The intracrine renin-angiotensin system. Clin Sci (Lond). 2012; 123:273-284. [PubMed: 22590974]

154. Szasz T, Bomfim GF, Webb RC. The influence of perivascular adipose tissue on vascular homeostasis. Vasc Health Risk Manag. 2013; 9:105-116. [PubMed: 23576873]

155. Yiannikouris F, et al. Adipocyte deficiency of angiotensinogen prevents obesity-induced hypertension in male mice. Hypertension. 2012; 60:1524-1530. [PubMed: 23108647] 
156. Bentley-Lewis R, et al. Body mass index predicts aldosterone production in normotensive adults on a high-salt diet. J Clin Endocrinol Metab. 2007; 92:4472-4475. [PubMed: 17726083]

157. Ehrhart-Bornstein M, Arakelyan K, Krug AW, Scherbaum WA, Bornstein SR. Fat cells may be the obesity-hypertension link: human adipogenic factors stimulate aldosterone secretion from adrenocortical cells. Endocr Res. 2004; 30:865-870. [PubMed: 15666838]

158. Ehrhart-Bornstein M, et al. Human adipocytes secrete mineralocorticoid-releasing factors. Proc Natl Acad Sci USA. 2003; 100:14211-14216. [PubMed: 14614137]

159. Jeon JH, et al. A novel adipokine CTRP1 stimulates aldosterone production. FASEB J. 2008; 22:1502-1511. [PubMed: 18171693]

160. Blanco-Rivero J, et al. Participation of prostacyclin in endothelial dysfunction induced by aldosterone in normotensive and hypertensive rats. Hypertension. 2005; 46:107-112. [PubMed: 15956108]

161. Garg R, Hurwitz S, Williams GH, Hopkins PN, Adler GK. Aldosterone production and insulin resistance in healthy adults. J Clin Endocrinol Metab. 2010; 95:1986-1990. [PubMed: 20130077]

162. Kithas PA, Supiano MA. Spironolactone and hydrochlorothiazide decrease vascular stiffness and blood pressure in geriatric hypertension. J Am Geriatr Soc. 2010; 58:1327-1332. [PubMed: 20533969]

163. Druppel V, et al. Long-term application of the aldosterone antagonist spironolactone prevents stiff endothelial cell syndrome. FASEB J. 2013; 27:3652-3659. [PubMed: 23729588]

164. Garg R, Kneen L, Williams GH, Adler GK. Effect of mineralocorticoid receptor antagonist on insulin resistance and endothelial function in obese subjects. Diabetes Obes Metab. 2014; 165:268-272. [PubMed: 24125483]

165. Pulakat L, et al. Adaptive mechanisms to compensate for overnutrition-induced cardiovascular abnormalities. Am J Physiol Regul Integr Comp Physiol. 2011; 301:R885-R895. [PubMed: 21813874]

166. Hwang MH, et al. Mineralocorticoid receptors modulate vascular endothelial function in human obesity. Clin Sci (Lond). 2013; 125:513-520. [PubMed: 23786536]

167. Schafer N, et al. Endothelial mineralocorticoid receptor activation mediates endothelial dysfunction in diet-induced obesity. Eur Heart J. 2013; 34:3515-3524. [PubMed: 23594590]

168. Byrd JB, Brook RD. A critical review of the evidence supporting aldosterone in the etiology and its blockade in the treatment of obesity-associated hypertension. J Hum Hypertens. 2014; 28:3-9. [PubMed: 23698003]

169. Tomaschitz A, Pilz S, Ritz E, Obermayer-Pietsch B, Pieber TR. Aldosterone and arterial hypertension. Nat Rev Endocrinol. 2010; 6:83-93. [PubMed: 20027193]

170. Ryan MJ. An update on immune system activation in the pathogenesis of hypertension. Hypertension. 2013; 62:226-230. [PubMed: 23734005]

171. Schiffrin EL. Immune mechanisms in hypertension and vascular injury. Clin Sci (Lond). 2014; 126:267-274. [PubMed: 24144355]

172. Lumeng CN, Bodzin JL, Saltiel AR. Obesity induces a phenotypic switch in adipose tissue macrophage polarization. J Clin Invest. 2007; 117:175-184. [PubMed: 17200717]

173. Britton KA, Fox CS. Perivascular adipose tissue and vascular disease. Clin Lipidol. 2011; 6:7991. [PubMed: 21686058]

174. Kalupahana NS, Moustaid-Moussa N, Claycombe KJ. Immunity as a link between obesity and insulin resistance. Mol Aspects Med. 2012; 33:26-34. [PubMed: 22040698]

175. Zhong, J., et al. T cell costimulation protects obesity-induced adipose inflammation and insulin resistance. Diabetes. http://dx.doi.org/10.2337/db13-1094

176. Liu G, et al. Phenotypic and functional switch of macrophages induced by regulatory $\mathrm{CD}^{+}{ }^{+} \mathrm{CD} 25^{+} \mathrm{T}$ cells in mice. Immunol Cell Biol. 2011; 89:130-142. [PubMed: 20514074]

177. Kassan M, Galan M, Partyka M, Trebak M, Matrougui K. Interleukin-10 released by CD4(+) $\mathrm{CD} 25(+)$ natural regulatory $\mathrm{T}$ cells improves microvascular endothelial function through inhibition of NADPH oxidase activity in hypertensive mice. Arterioscler Thromb Vasc Biol. 2011; 31:2534-2542. [PubMed: 21817097] 
178. Ohshima K, et al. Roles of interleukin 17 in angiotensin II type 1 receptor-mediated insulin resistance. Hypertension. 2012; 59:493-499. [PubMed: 22184328]

179. Stienstra R, Tack CJ, Kanneganti TD, Joosten LA, Netea MG. The inflammasome puts obesity in the danger zone. Cell Metab. 2012; 15:10-18. [PubMed: 22225872]

180. Akasheh RT, Pang J, York JM, Fantuzzi G. New pathways to control inflammatory responses in adipose tissue. Curr Opin Pharmacol. 2013; 13:613-617. [PubMed: 23648270]

181. Rathinam VA, Vanaja SK, Fitzgerald KA. Regulation of inflammasome signaling. Nat Immunol. 2012; 13:333-332. [PubMed: 22430786]

182. Conforti-Andreoni C, et al. Uric acid-driven Th17 differentiation requires inflammasome-derived IL-1 and IL-18. J Immunol. 2011; 187:5842-5850. [PubMed: 22058415]

183. Guzik TJ, et al. Role of the T cell in the genesis of angiotensin II induced hypertension and vascular dysfunction. J Exp Med. 2007; 204:2449-2460. [PubMed: 17875676]

184. Kasal DA, et al. T regulatory lymphocytes prevent aldosterone-induced vascular injury. Hypertension. 2012; 59:324-330. [PubMed: 22146512]

185. de Kloet AD, et al. Neuroimmune communication in hypertension and obesity: a new therapeutic angle? Pharmacol Ther. 2013; 138:428-440. [PubMed: 23458610]

186. Harrison DG, et al. Inflammation, immunity, and hypertension. Hypertension. 2011; 57:132-140. [PubMed: 21149826]

187. Abboud FM, Harwani SC, Chapleau MW. Autonomic neural regulation of the immune system: implications for hypertension and cardiovascular disease. Hypertension. 2012; 59:755-762. [PubMed: 22331383]

188. Dias da Silva VJ, Paton JF. Introduction: the interplay between the autonomic and immune systems. Exp Physiol. 2012; 97:1143-1145. [PubMed: 23114051]

189. Ganta CK, et al. Central angiotensin II- enhanced splenic cytokine gene expression is mediated by the sympathetic nervous system. Am J Physiol Heart Circ Physiol. 2005; 289:H1683-H1691. [PubMed: 15908469]

190. Turak O, et al. Serum uric acid, inflammation, and nondipping circadian pattern in essential hypertension. J Clin Hypertens (Greenwich). 2013; 15:7-13. [PubMed: 23282120]

191. Perez-Pozo SE, et al. Excessive fructose intake induces the features of metabolic syndrome in healthy adult men: role of uric acid in the hypertensive response. Int J Obes (Lond). 2010; 34:454-461. [PubMed: 20029377]

192. Chaudhary K, Kunal M, Sowers J, Aroor A. Uric acid-key ingredient in the recipe for cardiorenal metabolic syndrome. Cardiorenal Med. 2013; 3:208-220. [PubMed: 24454316]

193. Baldwin W, et al. Hyperuricemia as a mediator of the proinflammatory endocrine imbalance in the adipose tissue in a murine model of the metabolic syndrome. Diabetes. 2011; 60:1258-1269. [PubMed: 21346177]

194. Mazzali M, et al. Elevated uric acid increases blood pressure in the rat by a novel crystalindependent mechanism. Hypertension. 2001; 38:1101-1106. [PubMed: 11711505]

195. Tran LT, Yuen VG, McNeill JH. The fructose-fed rat: a review on the mechanisms of fructoseinduced insulin resistance and hypertension. Mol Cell Biochem. 2009; 332:145-159. [PubMed: 19536638]

196. Aroor A, et al. DPP-4 inhibitors as therapeutic modulators of immune cell function and associated cardiovascular and renal insulin resistance in obesity and diabetes. Cardiorenal Med. 2013; 3:4856. [PubMed: 23946724]

197. Ussher JR, Drucker DJ. Cardiovascular biology of the incretin system. Endocr Rev. 2012; 33:187-215. [PubMed: 22323472]

198. Lamers D, et al. Dipeptidyl peptidase 4 is a novel adipokine potentially linking obesity to the metabolic syndrome. Diabetes. 2011; 60:1917-1925. [PubMed: 21593202]

199. Wang B, et al. Blood pressure-lowering effects of GLP-1 receptor agonists exenatide and liraglutide: a meta-analysis of clinical trials. Diabetes Obes Metab. 2013; 15:737-749. [PubMed: 23433305] 
200. Aroor AR, et al. Dipeptidylpeptidase inhibition is associated with improvement in blood pressure and diastolic function in insulin resistant male Zucker obese rats. Endocrinology. 2013; 154:2501-2513. [PubMed: 23653460]

201. Kroller-Schon S, et al. Glucose-independent improvement of vascular dysfunction in experimental sepsis by dipeptidyl-peptidase 4 inhibition. Cardiovasc Res. 2012; 96:140-149. [PubMed: 22843705]

202. Hocher B, Reichetzeder C, Alter ML. Renal and cardiac effects of DPP4 inhibitors-from preclinical development to clinical research. Kidney Blood Press Res. 2012; 36:65-84. [PubMed: 22947920]

203. Asferg CL, et al. Relative atrial natriuretic peptide deficiency and inadequate renin and angiotensin II suppression in obese hypertensive men. Hypertension. 2013; 62:147-153. [PubMed: 23670298]

204. Yazbeck R, Howarth GS, Abbott CA. Dipeptidyl peptidase inhibitors, an emerging drug class for inflammatory disease? Trends Pharmacol Sci. 2009; 30:600-607. [PubMed: 19837468]

205. Shirakawa J, et al. Diet-induced adipose tissue inflammation and liver steatosis are prevented by DPP-4 inhibition in diabetic mice. Diabetes. 2011; 60:1246-1257. [PubMed: 21330637]

206. Shah Z, et al. Long-term dipeptidyl-peptidase 4 inhibition reduces atherosclerosis and inflammation via effects on monocyte recruitment and chemotaxis. Circulation. 2011; 124:2338 2349. [PubMed: 22007077]

207. Hadjiyanni I, Siminovitch KA, Danska JS, Drucker DJ. Glucagon-like peptide-1 receptor signalling selectively regulates murine lymphocyte proliferation and maintenance of peripheral regulatory T cells. Diabetologia. 2010; 53:730-740. [PubMed: 20225396]

208. McGill JB, et al. Potentiation of abnormalities in myocardial metabolism with the development of diabetes in women with obesity and insulin resistance. J Nucl Cardiol. 2011; 18:421-429. [PubMed: 21516378]

209. Peterson LR, et al. Alterations in left ventricular structure and function in young healthy obese women: assessment by echocardiography and tissue Doppler imaging. J Am Coll Cardiol. 2004; 43:1399-1404. [PubMed: 15093874]

210. Manrique C, et al. Obesity and insulin resistance induce early development of diastolic dysfunction in young female mice fed a western diet. Endocrinology. 2013; 154:3632-3642. [PubMed: 23885014]

211. Hinojosa-Laborde C, Chapa I, Lange D, Haywood JR. Gender differences in sympathetic nervous system regulation. Clin Exp Pharmacol Physiol. 1999; 26:122-126. [PubMed: 10065332]

212. Johnson MS, et al. Sex differences in baroreflex sensitivity, heart rate variability, and end organ damage in the TGR(mRen2)27 rat. Am J Physiol Heart Circ Physiol. 2011; 301:H1540-H1550. [PubMed: 21821781]

213. Denton KM, Hilliard LM, Tare M. Sex-related differences in hypertension: seek and ye shall find. Hypertension. 2013; 62:674-677. [PubMed: 23980069]

214. Pal S, Radavelli-Bagatini S. Association of arterial stiffness with obesity in Australian women: a pilot study. J Clin Hypertens (Greenwich). 2013; 15:118-123. [PubMed: 23339730]

215. Berry KL, et al. Large-artery stiffness contributes to the greater prevalence of systolic hypertension in elderly women. J Am Geriatr Soc. 2004; 52:368-373. [PubMed: 14962150]

216. Scuteri A, et al. Associations of large artery structure and function with adiposity: effects of age, gender, and hypertension. The SardiNIA Study. Atherosclerosis. 2012; 221:189-197. [PubMed: 22222417]

217. Meyer MR, Clegg DJ, Prossnitz ER, Barton M. Obesity, insulin resistance and diabetes: sex differences and role of oestrogen receptors. Acta Physiol (Oxf). 2011; 203:259-269. [PubMed: 21281456]

218. Ribas V, et al. Myeloid-specific estrogen receptor alpha deficiency impairs metabolic homeostasis and accelerates atherosclerotic lesion development. Proc Natl Acad Sci USA. 2011; 108:16457-16462. [PubMed: 21900603]

219. Maric-Bilkan C, Manigrasso MB. Sex differences in hypertension: contribution of the reninangiotensin system. Gend Med. 2012; 9:287-291. [PubMed: 22795464] 
220. Lindsey SH, Yamaleyeva LM, Brosnihan KB, Gallagher PE, Chappell MC. Estrogen receptor GPR30 reduces oxidative stress and proteinuria in the salt-sensitive female mRen2. Lewis rat. Hypertension. 2011; 58:665-671. [PubMed: 21844484]

221. Ricchiuti V, et al. Estradiol increases angiotensin II type 1 receptor in hearts of ovariectomized rats. J Endocrinol. 2009; 200:75-84. [PubMed: 18931023]

222. Lindsey SH, Chappell MC. Evidence that the G protein-coupled membrane receptor GPR30 contributes to the cardiovascular actions of estrogen. Gend Med. 2011; 8:343-354. [PubMed: 22153880]

223. Zhang R, Reisin E. Obesity-hypertension: the effects on cardiovascular and renal systems. Am J Hypertens. 2000; 13:1308-1314. [PubMed: 11130776]

224. Smink PA, et al. An initial reduction in serum uric acid during angiotensin receptor blocker treatment is associated with cardiovascular protection: a post-hoc analysis of the RENAAL and IDNT trials. J Hypertens. 2012; 30:1022-1028. [PubMed: 22388234]

225. Gupta AK, et al. Baseline predictors of resistant hypertension in the Anglo-Scandinavian Cardiac Outcome Trial (ASCOT): a risk score to identify those at high-risk. J Hypertens. 2011; 29:20042013. [PubMed: 21881528]

226. Mancia G, et al. 2013 Practice guidelines for the management of arterial hypertension of the European Society of Hypertension (ESH) and the European Society of Cardiology (ESC): ESH/ ESC Task Force for the Management of Arterial Hypertension. J Hypertens. 2013; 31:19251938. [PubMed: 24107724] 


\section{Key points}

- The incidence of hypertension is substantially increased in the population of people with obesity and affected individuals have increased morbidity and mortality from cardiovascular disease (CVD) and chronic kidney disease

- Adipokine alterations, insulin resistance, sympathetic nervous system and reninangiotensin-aldosterone system activation, obstructive sleep apnoea, renal abnormalities, maladaptive immunity and gut microbiome changes all link hypertension to obesity

- Hyperuricaemia associated with a high-fructose diet is emerging as a key factor in the development of hypertension associated with diet-induced obesity

- Dysregulation of the dipeptidyl peptidase 4-incretin system contributes to the development of maladaptive immunity and associated hypertension in obesity

- Estrogen-mediated CVD protection is compromised in individuals with obesity, thereby underscoring the greater CVD risks associated with obesity in premenopausal women compared with those in age-matched men with obesity

- Adjunctive therapy with mineralocorticoid receptor antagonists and renal denervation is emerging as an additional therapeutic measure for management of obesity-related hypertension 


\section{Review criteria}

MEDLINE and PubMed databases were searched for full-text English-language articles published between 1950 and 2014 with the following terms: "obesity", "resistant hypertension", "insulin resistance", "obstructive sleep apnea", "SNS activation”, "high fructose corn syrup", "uric acid", "endothelial dysfunction", "DPP-4", "tissue RAAS", "aldosterone", "adipose dysfunction", "gut microbiome", both alone and in combination. The reference lists of identified articles were also consulted for other relevant papers. 


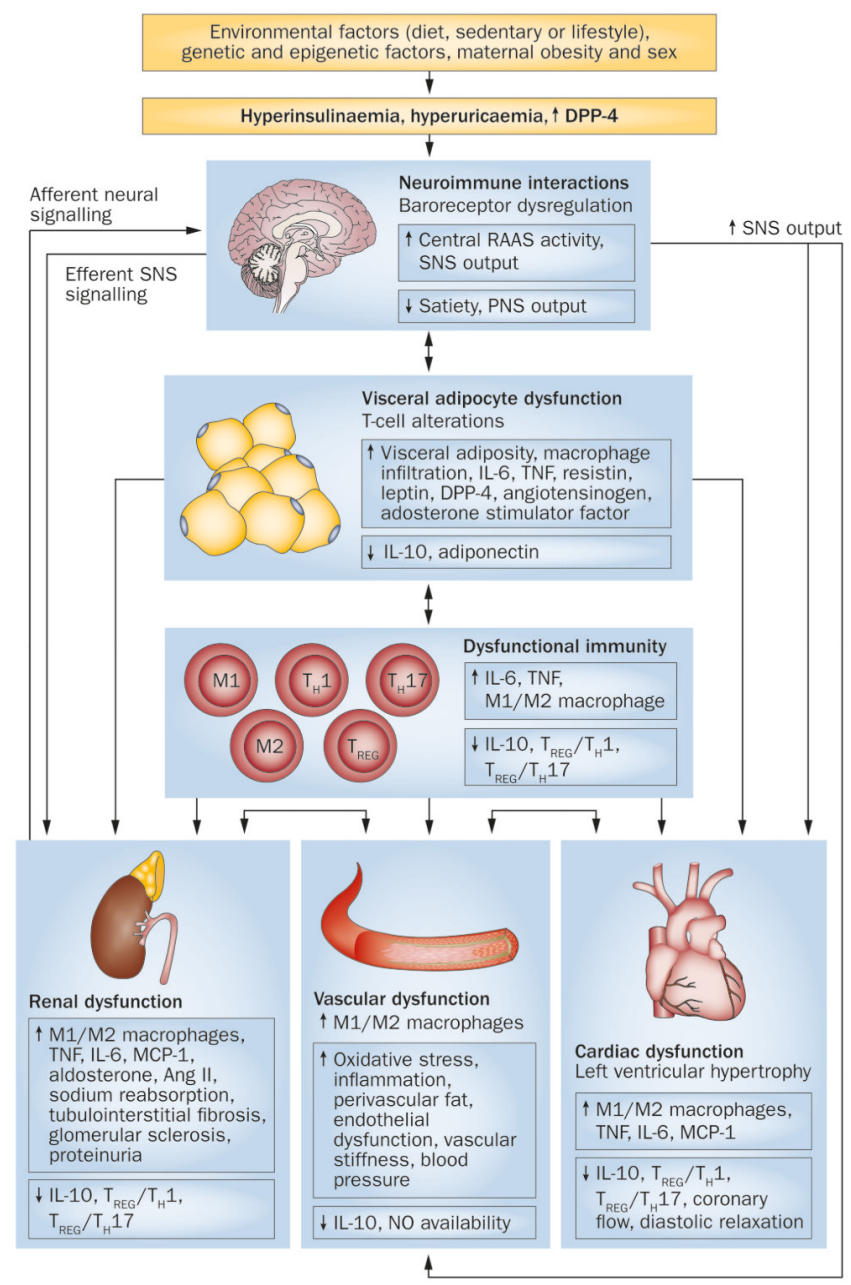

Figure 1.

Obesity contributes to the development of hypertension via the interaction of dietary, genetic, epigenetic and environmental factors. Visceral adipocyte dysfunction leads directly to renal, cardiac and vascular dysfunction, via an impaired immune or inflammatory response, and by affecting neuroimmune interactions that alter SNS signalling. Cardiac and/or renal abnormalities can lead to vascular dysfunction and vice-versa. Obesity-related hypertension is associated with structural and functional changes in the kidney, heart and vasculature. Hyperuricaemia might also affect adipocyte function and vascular remodelling, and cause renal abnormalities. Abbreviations: $\uparrow$, increased; $\downarrow$, decreased; Ang II, angiotensin II; DPP-4, dipeptidyl peptidase 4; MCP-1, monocyte chemoattractant protein-1; PNS, parasympathetic nervous system; RAAS, renin-angiotensin-aldosterone system; SNS, sympathetic nervous system; $\mathrm{T}_{\mathrm{H}}, \mathrm{T}$ helper cell; $\mathrm{T}_{\mathrm{REG}}, \mathrm{T}$ regulatory cell. 


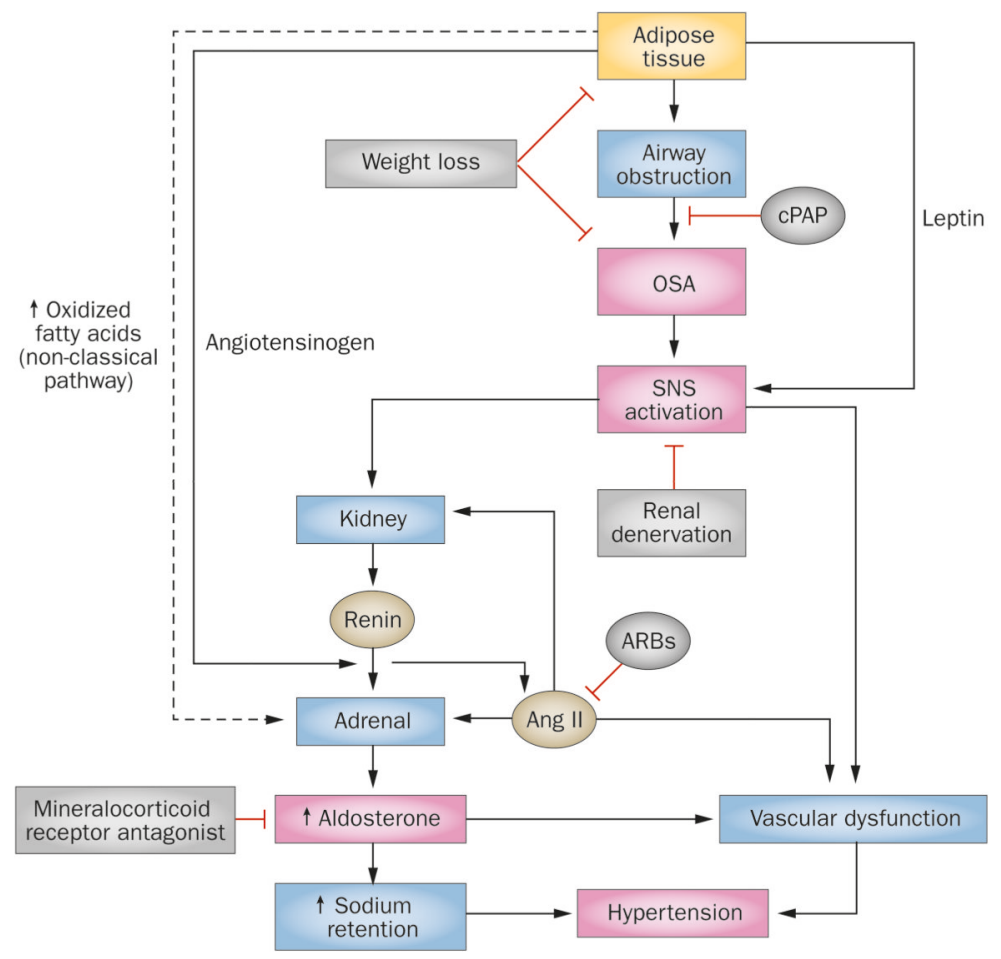

Figure 2.

Possible mechanisms of obesity-associated hypertension and therapeutic strategies. Adipose tissue releases leptin, angiotensinogen and oxidized fatty acids to stimulate adrenal release of aldosterone via activation of the classic RAAS, as well as a non-classical pathway mediated by oxidized fatty acids. Leptin stimulates the central SNS which in turn leads to renin release from the kidney. Activation of RAAS in other tissues contributes to renal and vascular dysfunction. Increased adipose tissue can lead to OSA, which can be treated by therapeutic weight loss or application of cPAP. OSA leads to activation of the SNS which activates RAAS in the kidney. Increased aldosterone can be reduced with mineralocorticoid receptor antagonists. Abbreviations: $\uparrow$, increased; $\downarrow$, decreased; ARBs, angiotensin type 1 receptor blockers; cPAP, continuous positive airway pressure; OSA, obstructive sleep apnoea; RAAS, renin-angiotensin-aldosterone system; SNS, sympathetic nervous system. 